\title{
ANALISIS KELAYAKAN USAHA AGROINDUSTRI TAHU PUTRA LAKSANA (Studi Kasus di Kelurahan Mangkubumi Kecamatan Mangkubumi Kota Tasikmalaya)
}

\author{
FEASIBILITY ANALYSIS OF TAHU PUTRA LAKSANA AGROINDUSTRY \\ (A Case Study in Mangkubumi Village, Mangkubumi District, Tasikmalaya City) \\ SINTIA ${ }^{*}$, DINI ROCHDIANI ${ }^{1}$, DANI LUKMAN HAKIM ${ }^{1}$ \\ ${ }^{1}$ Fakultas Pertanian, Universitas Galuh \\ ${ }^{2}$ Fakultas Pertanian, Universitas Padjajaran \\ *E-mail: tyasintia1997@gmail.com
}

\begin{abstract}
ABSTRAK
Penelitian ini bertujuan untuk : 1) mengetahui rasio B/C, rasio R/C dan BEP produksi serta BEP harga usaha pembuatan tahu pada industri Rumah Tangga Putra Laksana (PLS) 2) menganalisa kelayakan usaha pembuatan tahu pada Industri Rumah Tangga Putra Laksana (PLS). Metode penelitian ini adalah Studi Kasus sehingga pemilik usaha pembuatan tahu pada Industri Rumah Tangga Putra Laksana (PLS) dijadikan sebagai sumber untuk memperoleh informasi sesuai yang dibutuhkan oleh peneliti. Hasil penelitian menunjukkan bahwa besarnya biaya produksi rata-rata yang diperlukan oleh perajin tahu Putra Laksana (PLS) yang berada di Kelurahan Mangkubumi Kecamatan Mangkubumi Kota Tasikmalaya sebesar Rp 3.599.359,87 dalam satu kali proses produksi. Penerimaan rata-rata yang diperoleh perajin tahu Putra Laksana (PLS) sebesar Rp 6.300.000 dengan diperoleh pendapatan Rp 2.700.640,13 untuk satu kali proses produksi. Berdasarkan Perhitungan kelayakan usaha R/C sebesar 1,75 artinya setiap Rp 1,00 biaya yang dikeluarkan akan menerima keuntungan sebesar Rp 0,75 , sementara itu perhitungan $\mathrm{B} / \mathrm{C}$, yaitu perbandingan keuntungan dengan total biaya adalah 0,75 atau $0,75>0$. Demikian juga perhitungan BEP produksi sebesar 1.599,71 dan BEP harga jual sebesar Rp. 1.333,09. Dengan demikian dapat disimpulkan bahwa usaha agroindustri tahu Putra Laksana (PLS) menguntungkan dan layak untuk diusahakan.
\end{abstract}

Kata kunci: Agroindustri, kelayakan, tahu.

\section{ABSTRACK}

This study aimed : 1). To know the ratio of $B / C, R / C$ production and price BEP of Putra Laksana Tofu Agroindustry Household industry (PLS) 2) feasibility of analysis Putra Laksana (PLS). The method of the study was Case Study, this the owner of Putra Laksana agroindustry was taken as a respondent. The results showed that: The average production cost was $R p .3,599,359.87$ in one production process. The average revenue obtained was $R p$. 6,300,000 with an income of $R p$. 2,700,640.13 for one production process. Based on the calculation of feasibility analysis $R / C$ shaved was 1.75 , it means that every $R p .1 .00$ of the costs incurred will receive a profit of $R p .0 .75$, while the calculation of $B / C$, as the comparison of profits and the total cost was 0.75 or $0.75>0$. Atherwise the production BEP was 1,599.71 and BEP of the selling price was Rp. 1,333.09. It concluded that the Putra Laksana Tofu Agroindustry is profitable and feasible.

Keywords: Agroindustry, Tofu, Feasibility. 


\section{PENDAHULUAN}

Sektor industri pengolahan merupakan salah satu penyumbang dalam memantapkan perekonomian di Indonesia. Saat ini Indonesia memiliki banyak produk pangan yang diangkat dari jenis pangan lokal dan diolah secara tradisional. Soleh (2003) menyatakan bahwa jumlah dan jenis produk pangan menjadi semakin banyak jumlahnya dengan berkembangnya produk lokal.

Tahu adalah kedelai yang diproses dengan menghancurkan biji kedelai dengan air dingin atau panas.Tahap pengolahannya meliputi pembersihan, perendaman, penghancuran, pengeringan, pemanasan, serta penambahan rasa dan aroma.Tahu merupakan menu yang sering dikonsumsi masyarakan sebagai sumber protein yang relatif murah harganya.

\section{METODE PENELITIAN}

Jenis penelitian yang akan digunakan adalah studi kasus pada Agroindustri Tahu Putra Laksana (PLS) yang berlokasi di Jalan Babakan Karangkawitan, Kelurahan Mangkubumi, Kecamatan Mangkubumi, Kota Tasikmalaya.

Data yang akan digunakan dalam penelitian berupa data primer yang diperoleh melalui wawancara langsung ke responden dan data sekunder yang diperoleh dari dinas ataupun intansi yang berkaitan dengan penelitian.

Teknik penarikan sampel dilakukan secara sengaja (Purposive Sampling) terhadap Pengusaha Agroindustri Pengolahan Kedelai yang dilakukan oleh Agroindustri Tahu Putra Laksana (PLS) dengan pertimbangan bahwa usaha tersebut merupakan satu-satunya perusahaan yang mengolah tahu di Kelurahan Mangkubumi. Selain itu juga merupakan suatu mata pencaharian menjanjikan yang sudah sejak tahun 2008 dilakukan secara berkelanjutan. Menurut Nasehudin dan Gozali (2012) menyatakan bahwa teknik pengambilan sampel menggunakan purposive sampling, yaitu sampel yang dipilih secara sengaja atas pertimbangan tertentu atau tidak acak.

Untuk mengetahui besarnya biaya produksi, penerimaan, pendapatan, dan $\mathrm{R} / \mathrm{C}$, adalah sebagai berikut:

1) Analisis Biaya

Untuk menghitung besarnya biaya total (Total Cost) diperoleh dengan cara menjumlahkan biaya variabel (Variable Cost) dengan biaya tetap (Fixed Cost) dengan rumus:

$\mathrm{TC}=\mathrm{FC}+\mathrm{VC}$

Keterangan:

TC: Total Cost (Biaya Total)

FC: Fixed Cost (Total Biaya Tetap Total) 
VC: Variable Cost (Total Biaya Variabel Total)

2) Analisis Penerimaan

Secara umum perhitungan total penerimaan (Total Revenue/TR) adalah perkalian antara jumlah produksi (Y) dengan harga jual (Py) dengan rumus sebagai berikut:

$\mathrm{TR}=\mathrm{Y} . \mathrm{Py}$

Keterangan:

TR: Total Revenue (Penerimaan Total)

Y: Produksi yang diperoleh

Py: Harga satuan produk

3) Analisis Pendapatan

Pendapatan adalah selisih antara penerimaan (TR) dan biaya total (TC) dan dinyatakan dengan rumus:

$\mathrm{Pd}=\mathrm{TR}-\mathrm{TC}$

Keterangan:

Pd: Pendapatan.

TR:Total Revenue (Penerimaan Total)

TC:Total Cost (Biaya Total)

4) $\mathrm{R} / \mathrm{C}$

$\mathrm{R} / \mathrm{C}$ adalah perbandingan antara penerimaan dengan biaya total, dinyatakan dengan rumus:

$\mathrm{R} / \mathrm{C}=\frac{\text { Penerimaan Total }}{\text { Biaya Total }}$

Dengan asumsi:

a. $\mathrm{R} / \mathrm{C}<1$, maka usaha tersebut rugi.

b. $\mathrm{R} / \mathrm{C}=1$, maka usaha tersebut tidak untung tidak rugi (impas). c. $\mathrm{R} / \mathrm{C}>1$, maka usaha tersebut untung sehingga layak diusahakan.

\section{HASIL DAN PEMBAHASAN}

\section{Umur Responden}

Umur adalah faktor yang mempengaruhi terhadap keberhasilan dalam melakukan sutau kegiatan usaha dan juga akan berpengaruh terhadap kemampuan fisik dalam bekerja dan cara berfikir. Responden yang diambil adalah seorang perajin Agroindustri Tahu Putra Laksana (PLS) yang bernama Imin Muslimin yang tahun ini berusia 41 tahun.

\section{Pengalaman Berusaha Agroindustri}

Soeharjo dan Patong (1984) Pengalaman berusaha dikatakan cukup apabila telah menggeluti pekerjaan berusaha selama 5-10 tahun, sedangkan untuk 10 tahun keatas dikategorikan berpengalaman dan kurang dari 5 tahun dikategorikan kurang berpengalaman. Usaha Agroindustri Tahu Putra Laksana (PLS) yang beralamat di Kelurahan Mangkubumi Kecamatan Mangkubumi sudah berpengalaman berusaha selama 12 tahun dan dapat di kategorikan sudah berpengalaman.

\section{Tingkat Pendidikan Responden}

Pendidikan merupakan suatu upaya untuk memperbaiki nasib dan peradaban manusia serta untuk mewariskan nilai yang 
akan menjadi penolong dan penentu manusia dalam menjalani kehidupannya (Martono, 2012). Perajin Agroindustri Tahu Putra Laksana (PLS) yang berada di Kelurahan Mangkubumi adalah lulusan Sekolah Menengah Pertama. Meskipun begitu usaha Agroindustri Tahu Putra Laksana (PLS) dapat beroperasi dengan baik hingga berkembang dan menghasilkan keuntungan.

\section{Tanggungan Keluarga}

Yang termasuk jumlah anggota keluarga adalah seluruh jumlah anggota keluarga rumah tangga yang tinggal dan makan dari satu dapur dengan kelompok penduduk yang sudah termasuk dalam kelompok tenaga kerja (Mantra 2003). Perajin usaha Agroindustri Tahu Putra Laksana (PLS) yang berada di Kelurahan Mangkubumi Kecamatan Mangkubumi Kota Tasikmalaya ini memiliki tanggungan keluarga lima orang yang terdiri dari suami, istri dan tiga orang anak.

\section{Analisis Usaha Agroindustri Tahu}

1) Analisis Biaya.

$$
\text { Biaya produksi adalah }
$$
penjumlahan dari biaya yang dikeluarkan untuk setiap satu kali proses produksi, yang terdiri atas biaya tetap dan biaya variabel. Untuk lebih jelasnya dapat dilihat pada Tabel 8.
Tabel 8. Rata-rata Biaya Produksi Usaha

Agroindustri Tahu dalam Satu

Kali Proses Produksi di

Kelurahan Mangkubumi

\begin{tabular}{llr}
\hline No. & \multicolumn{1}{c}{ Uraian } & \multicolumn{1}{c}{$\begin{array}{c}\text { Besarnya } \\
\text { Biaya (Rp) }\end{array}$} \\
\hline 1. & Biaya Tetap & \\
& Pajak Bumi dan & 168,07 \\
& Bangunan & 1704,2109 \\
& Bunga Modal Tetap & $24.191,8$ \\
& $7 \%$ & \\
& Penyusutan Alat & \\
& Total Biaya tetap & $26.050,08$ \\
2. & Biaya Variabel & \\
& Kedelai & 2.100 .000 \\
& Plastik & 210.000 \\
& Kayu Bakar & 360.000 \\
& Transportasi & 100.000 \\
& Tenaga Kerja & 545.000 \\
& Listrik & 50.000 \\
& Garam & 210.000 \\
& Bunga $\quad$ Total & 250.250 \\
& Variabel 7\% & \\
& Total $\quad$ Biaya & 3.825 .250 \\
& Variabel & \\
\hline 3. & Biaya Total & $3.851 .300,08$ \\
\hline
\end{tabular}

Tabel 8 menunjukkan bahwa rata-rata biaya total perajin tahu dalam satu kali proses produksi adalah Rp 3.851.300,08.merupakan penjumlahan dari biaya tetap dan biaya variabel.

2) Analisis Penerimaan

Penerimaan yang diperoleh perajin agroindustri tahu adalah jumlah tahu yang dihasilkan dikalikan dengan harga tahu per buah yang berlaku pada saat penelitian. Rata-rata biaya produksi yang dikeluarkan tiap satu kali proses produksi Rp 3.851.300,08.- sedangkan dalam satu kali produksi rata-rata mendapat penerimaan Rp 6.300.000.- dengan demikian rata-rata 
perajin memperoleh pendapatan $\mathrm{Rp}$ 2.448.699,92.-

3) Analisis $\mathrm{R} / \mathrm{C}$

Dengan nilai $\mathrm{R} / \mathrm{C}$, dapat diketahui apakah suatu usaha menguntungkan atau tidak menguntungkan. Usaha efisiensi (menguntungkan) jika nilai $\mathrm{R} / \mathrm{C}>1$. Ratarata $\mathrm{R} / \mathrm{C}$ usaha agroindustri tahu Putra Laksana (PLS) di Kelurahan Mangkubumi dapat diketahui dengan rumus sebagai berikut:

$$
\begin{aligned}
\mathrm{R} / \mathrm{C}=\frac{\text { Rata rata penerimaan total }}{\text { Rata rata biaya total }} \\
=\frac{6.300 .000}{3.851 .300,08} \\
=1,63
\end{aligned}
$$

Berdasarkan hasil Perhitungan diketahui bahwa usaha agroindustri tahu yang ada di Kelurahan Mangkubumi memiliki nilai rata-rata $\mathrm{R} / \mathrm{C} 1,63(\mathrm{R} / \mathrm{C}>1)$, hal ini menunjukkan bahwa dari setiap satu rupiah biaya yang dikeluarkan, perajin akan memperoleh penerimaan $\mathrm{Rp}$ 1,63, dan pendapatan atau keuntungan 0.63 rupiah, sehingga dapat dikatakan bahwa usaha agroindustri tahu yang dijalankan perajin adalah menguntungkan.

\section{KESIMPULAN DAN SARAN}

\section{Kesimpulan}

Berdasarkan hasil penelitian dan pembahasan maka dapat diambil kesimpulan sebagai berikut:
1. Rata-rata biaya total pada Agroindustri Tahu Putra Laksana (PLS) yang berada di Kelurahan Mangkubumi Kecamatan Mangkubumi Kota Tasikmalaya adalah Rp 3.851.300,08.- sedangkan penerimaan adalah $\mathrm{Rp}$ 6.300.000.per satu kali proses produksi sehingga diperoleh rata-rata pendapatan Rp. 2.448.699,92.

2. Rata-rata $\mathrm{R} / \mathrm{C}$ pada Agroindustri Tahu Putra Laksana (PLS) di Kelurahan Mangkubumi Kecamatan Mangkubumi Kota Tasikmalaya adalah 1,63 hal ini menunjukkan bahwa dari setiap satu rupiah biaya yang dikeluarkan, perajin akan memperoleh penerimaan $\mathrm{Rp}$ 1,63, dan pendapatan atau keuntungan 0.63 rupiah, sehingga dapat dikatakan bahwa usaha agroindustri tahu yang dijalankan perajin adalah menguntungkan.

\section{Saran}

Berdasarkan hasil penelitian dan pembahasan, untuk meningkatkan pendapatan, disarankan usaha agroindustri tahu Putra Laksana (PLS) untuk menambahkan jumlah produksi, dan memperluas pasar.

Sebaiknya perajin membuat laporan usaha sehingga tidak tercampur dengan 
keuangan pribadi serta kegiatan usaha dapat tercatat dengan baik untuk kepentingan administrasi yang nantinya akan membantu untuk memajukan usahanya karena terkonsep dengan baik pula

\section{DAFTAR PUSTAKA}

Kertaatmaja. 2001. Analisis Usaha Pembuatan Tempe Kedelai di Kabupaten Purwerejo. J Agroland 22(2) :169-174.
Nasehudin, dan Gozali. 2012. Metode Penelitian Kuantitatif. Bandung: CV PustakaSetia.

Soleh. 2003. Analisis Keuntungan dan Kelayakan Usaha Pembuatan Tahu di Kelurahan Liauku Kecamatan Bungi Kota Bau-Bau (Studi Kasus industri Tahu Mekar). AgriSosioekonomi Unsrat Volume 13 N0.1A :155-168.

Suratiyah. 2015. Ilmu Usaha Tani. Penebar Swadaya. Jakarta

Martono, N. 2012. Sosiologi Perubahan Sosial: Persepektif Klasik, Modern, Posmodern, dan Poskolonial. Rajawali Pers. Jakarta.

Mantra, Ida Bagus. 2003. Demografi Umum. Pustaka Raja. Jakart 